\title{
Examining the Mechanism on Ventilation for Thermal Comfort in Residential Buildings: A Case of Government Housing Estates in Nigeria
}

\author{
Ayeni Conqueror Ayoariyo', Atolagbe A.M. O \\ ${ }^{12}$ Department of Architecture, Ladoke Akintola University of Technology, Ogbomoso, Oyo State Nigeria.
}

\begin{abstract}
Natural has been agreed to be an energy efficient alternative for reducing the energy use in buildings, achieving thermal comfort and maintaining a healthy indoor environment. The study examines the mechanism on ventilation for thermal comfort in residential buildings of selected government housing estate in south-west Nigeria. Limited research has been recorded on the study of mechanism on ventilation for thermal comfort in residential buildings. Based on the survey results, it was found that while achieving natural ventilation through it mechanism

$78.0 \%$ were window, $12.5 \%$ soft landscape elements while the combination of window and courtyard were $9.5 \%$. The study therefore concluded that windows with adequate sizes and landscape elements should be adopted for the enhancement of natural ventilation in residential buildings.
\end{abstract}

Keywords: Landscape, windows, Courtyard, residential buildings, thermal comfort, South-West Nigeria. 


\section{Introduction}

During warm and hot weather periods, naturally ventilated buildings rely almost completely on wind to generate the required fresh air movement through the building. Building orientation is best determined using local wind patterns. To take advantage of warm weather winds, the building fenestrations should be perpendicular to the prevailing warm weather winds. In lieu of localized wind patterns, 'wind roses' can be used to position naturally ventilated buildings so as to take advantage of warm weather winds. Wind roses are the summaries of wind patterns and wind speeds for various weather stations across any country. Since winds generally shift between seasons of the year, it is important that patterns for summer winds be selected. The percent time of calm days is a very important parameter in relation to naturally ventilated buildings. Significant periods of calm days combined with warm temperatures result in inadequate fresh air entering the building and an unacceptable increase of inside temperature. (WHO,2009).

However in Nigeria, limited research has been done on the mechanism of ventilation in residential buildings. This study therefore looks at the mechanism of thermal comfort and sustainability in residential buildings which is primarily attainable through natural ventilation. In addressing the thermal comfort in the study area, the following research questions address the mechanism of ventilation:

(i) How are natural ventilation provided in residential buildings?

(ii) What is the effect of court yard in the residential buildings?

(iii) Do landscape elements have impact on the flow of air into the residential buildings?

\section{Literature Review}

Open spaces around buildings ensure adequate circulation, ventilation and day lighting (Tipple, 2001). The quantity of open spaces around buildings determines the space that is left for outdoor landscape features and outdoor activities. There is a working relationship between landscaping and open space management and there is deep need for "Adequate knowledge of the concept of open spaces and its super imposition on other concepts such as garden, parks and landscaping in general". Fadamiro and Atolagbe (2006) denoted landscaping as the process of shaping, modifying and creating an ordered outdoor scene for functional and supportive roles. Such functions include accent, softening, dust screening, framing, shading, enclosure, circulation control, noise control and surfacing. Indeed, the importance of landscaping of open spaces around buildings cannot be overemphasized. Thus, the treatment of residential environments has been discovered to have impact on the health, 
productivity and recreation of urban dwellers just as landscaping around homes lead to reduction of environmental pollution (Jagboro, 2000). The converse of this discovery is also true. For instance, Oyelami (2005) linked the use of artificial objects around homes with negative effects on health of dwellers. Campbell (2001) posited that open spaces has potential to provide environmental and social benefits to communities, whether directly or indirectly. Landscape elements can be generally grouped into hard and soft classes. Hard landscape elements are usually structural in nature. They include paving, stones, and asphalt and they are generally less desirable. On the other hand, soft landscape materials are more desirable and include grass cover, shrubs, palms and trees. According to Braines (2000), there exists a complex relationship between trees and people. In the words of Azwar and Ghain (2009), they provide "The sound of birds, the seasonal display of blossom fruit and changing leaf colour and splendour". They further added that, domestic gardens in particular offer privacy, security and the opportunity for individuality and have been recognized as providing a soft and sheltered setting for the buildings in contrasts to the harshness of buildings and the noise and grime of busy traffic (Jones, 2001). Companies of trees and natural surroundings can also provide measurable stress relief. Ignorance of these benefits of landscaping among others is the bane of the poor urban environmental aesthetics and function. Lasisi and Arowosegbe (2005) in their study of urban landscaping problems in Ilaro, Nigeria, discovered that, misconceptions and ignorance of these benefits hindered majority of respondents from landscaping and maintenance of green open spaces around their dwellings. In residential designs generally, there is usually the provision of the equivalent indoor room as the outdoor rooms. Outdoor room usually have floors of ground cover, concrete paving or timber finish, outdoor walls of plant hedges, sandcrete wall fence or see-through wire fencing depending on the purpose and outdoor ceiling of the natural sky. Adjacent to the living room is the outdoor living provided under a shading tree with ground cover or timber floor patio. Indoor sleeping area is also provided with equivalent adjacent outdoor sleeping area with landscape elements. While the outdoor living and sleeping areas/rooms are used for relaxation, the outdoor kitchen near the indoor kitchen is used for the major service of outdoor cooking which may be heavy occasionally. Indeed, a balance in the quality of the indoor and outdoor spaces of an architectural structure determines the quality of the entire living environment both at micro (plot) and neighbourhood scales. Akingbohungbe (2003) remarked that they exact profound impact on the lifestyle, health, happiness, integrity and productivity of residents. Fadamiro (2000) posited that, provision of outdoor spaces in development is an essential and integral contributor to the quality of life. In the view of Carmona et al (2003), well-designed landscaping of open spaces adds quality, visual interest and colour. 
It is for these reasons and the earlier stated ones that, The Building Adoptive Bye-Laws Order 1960 for Nigeria specifies in section 8 that:

1). There shall be an open space not less than five feet six inches $(1.65 \mathrm{~m})$ in width between any building and the side boundary of the site where the height of the building does not exceed twenty-five feet $(7.50 \mathrm{~m})$, and an open space not less than ten feet $(3.00 \mathrm{~m})$ in width where the height of the building exceeds twenty-five feet $(7.50 \mathrm{~m})$.

2). Where the height of any main building does not exceed twenty-five feet $(7.50 \mathrm{~m})$, there shall be an open space of ten feet $(3.00 \mathrm{~m})$ in width between the main building and the out-houses appertaining thereto; where the height of the main building exceeds twenty-five feet $(7.50 \mathrm{~m})$ but does not exceed forty feet $(12.00 \mathrm{~m})$, such open space shall not be less than fifteen feet $(4.50 \mathrm{~m})$ in width, and, where the height of the main building exceeds forty feet $(12.00 \mathrm{~m})$ such open space shall not be less than twenty feet in width $(6.0 \mathrm{~m})$.

The importance of the treatment of the open spaces around residential buildings brought about the specification of the required height of the fence in Section 21 of the law as follows:

1). The maximum height of fences (including live fences) around any building site shall be fifteen feet $(4.50 \mathrm{~m})$ except in respect of building sites abutting the junction of two or more highways; in which case, fences shall be kept sufficiently low to permit clear visibility around the corner for motorists and other road users.

2). In the case of dwelling houses on small plots not exceeding half an acre in area, no boundary walls or fences shall exceed seven feet $(2.10 \mathrm{~m})$ in height.

\section{Research Methodology}

\section{Sampling Frame}

The sample frame is Owode Estate Apata, Ibadan and using the road network of the estate, the choice of zones was based on the sizes of the estate: since the estate was basically characterized by less dense development, in order to achieve a good and reliable sample frame, notable area in which their boundaries were obvious was used as a criterion for the selection.

A total of six (6) estate zones were sampled altogether and they include: first gate, second gate, northern side, southern side, central and Anglican church side of the estate. 


\section{Sample size and Sampling Technique}

Systematic random sampling was used for the study. The first building was chosen at random, while others were chosen at interval of five (5) buildings along each street. In all, a total of one hundred and sixty-three (163) residents of the area was chosen for questionnaire administration thereby, representing $5 \%$ of the population. This is shown in Table 3.1

Table 3.1: Sample size

\begin{tabular}{|c|c|c|}
\hline Zone & No. of Buildings & $\begin{array}{c}\text { No. of Questionnaires } \\
\text { Administered }\end{array}$ \\
\hline First gate & 357 & 18 \\
\hline Second gate & 752 & 38 \\
\hline Northern side & 430 & 22 \\
\hline Southern side & 400 & 32 \\
\hline Central & 632 & 34 \\
\hline $\begin{array}{c}\text { Anglican } \\
\text { church side }\end{array}$ & 689 & $\mathbf{1 6 3}$ \\
\hline Total & $\mathbf{3 2 6 0}$ & \\
\hline
\end{tabular}

Source: Author's Fieldwork (2018).

Table 3.6: Mechanisms used for achieving ventilation. 
$2^{\text {nd }}$ International Conference on Advanced Research in

Applied SCIENCE \& ENGINEERING

27 - 29 MARCH, 2020

Oxford, United Kingdom

\begin{tabular}{|c|c|c|}
\hline Mechanism & $\begin{array}{c}\text { Frequency } \\
(\mathbf{N})\end{array}$ & $\begin{array}{c}\text { Percentage } \\
(\boldsymbol{\%})\end{array}$ \\
\hline Window & 127 & 78.0 \\
Window and courtyard & 15 & 9.5 \\
Landscape element & 21 & 12.5 \\
\hline Total & $\mathbf{1 6 3}$ & $\mathbf{1 0 0}$ \\
\hline
\end{tabular}

Source: Author's Fieldwork, (2015).

There are three mechanisms used for natural ventilation in the area. These are: window, courtyard and landscape elements. The bulk of the respondents used window (78.0\%), (9.5\%) respondents used the combination of window and courtyard, while only (12.5\%) respondents adopted landscape elements (Table 3.6)

Out of the respondents that utilized window, casement window constituted (36.5\%) while louver blade was $(31.0 \%)$. Also, projected window type was $(22.0 \%)$, with sliding window being $(10.5 \%)$ as shown in table 3.7 .

Table 3.16: Landscape elements

\begin{tabular}{|c|c|c|}
\hline Elements & $\begin{array}{c}\text { Frequency } \\
(\mathbf{N})\end{array}$ & $\begin{array}{c}\text { Percentage } \\
(\boldsymbol{\%})\end{array}$ \\
\hline Green area/ shrubs & 20 & 12.2 \\
Interlocking stone & 86 & 52.8 \\
Concrete paving & 57 & 35.0 \\
\hline Total & $\mathbf{1 6 3}$ & $\mathbf{1 0 0}$ \\
\hline
\end{tabular}

Source: Author's Fieldwork, (2015).

Types of Landscape elements. 
The table below revealed different landscape elements mostly used in the study area, with (12.2\%) of soft landscape element: grass and shrub and (87.8\%) of hard landscape elements. The implication of this is that, there were more dissatisfaction emanating from outside into the building.

Table 3.12 (a): Presence of courtyard and its benefit.

\begin{tabular}{|c|c|c|}
\hline $\begin{array}{c}\text { Presence of courtyard } \\
\text { Yes }\end{array}$ & $\begin{array}{c}\text { Prequency } \\
(\mathbf{N})\end{array}$ & $\begin{array}{c}\text { Percentage } \\
(\boldsymbol{\%})\end{array}$ \\
\hline No & 15 & 9.2 \\
& 148 & 90.8 \\
\hline Total & $\mathbf{1 6 3}$ & $\mathbf{1 0 0}$ \\
\hline
\end{tabular}

b)

\begin{tabular}{|c|c|c|}
\hline Benefit & $\begin{array}{c}\text { Frequency } \\
(\mathbf{N})\end{array}$ & $\begin{array}{c}\text { Percentage } \\
(\boldsymbol{\%})\end{array}$ \\
\hline Ventilation & 47 & 29.0 \\
Beautification & 31 & 19.0 \\
High cost of maintenance & 85 & 52.0 \\
\hline Total & $\mathbf{1 6 3}$ & $\mathbf{1 0 0}$ \\
\hline
\end{tabular}

Source: Author's Fieldwork, (2015).

\subsubsection{Presence of courtyard and its benefit.}

Presence of analysis indicated that, (9.2\%) of the respondents utilized courtyard in the building, while the bulk of the respondents $(90.8 \%)$ did not use it. For the respondents that used courtyard, the benefits include ventilation (29.0\%), beautification (19.0\%) and high cost of maintenance (52.0\%).

\section{Conclusion}

40 
The essence of green building is gradually seeping into countries like Nigeria. The introduction of naturally ventilated buildings, although new will definitely be accepted with time and creating an environment that is soothing and calming to all users is of prime importance. This research work has contributed to the relevant knowledge of designing a naturally ventilated residential facility. It proposes a design that incorporates garden and a well naturally ventilated building to suit the culture and climate of the recipients. Nature is interwoven with the built environment through the use of landscaping elements and open-spaces to create a place of beauty, simplicity and natural healing for the terminally ill and their families.

Recommendations: The study hereby recommends that; landscape elements should be adopted for the enhancement of natural ventilation in residential buildings as well as the use of louver or casement window of adequate sizes.

\section{References}

Afon; A.O. (1997). Perception of Environmental quality of the core of Ogbomoso in Oyo

State.

An Unpublished work for the Degree of Master of Science, at the Obafemi Awolowo University (OAU), Ile-Ife, Nigeria.

Akande, O. K. and Adebamowo, M. O. (2010): Indoor Thermal Comfort for Residential Buildings in Hot-Dry .Climate of Nigeria. Proceedings of Conference: Adapting to Change: New Thinking on Comfort Cumberland Lodge, Windsor, UK, 9-11 April 2010. London: Network for Comfort and Energy Use in Buildings, http://nceub.org.uk

Akingbohungbe, D.O. (2003a). “Adequate Housing and Sustainable Development in Nigeria” Journal of Urban and Environmental Research 3(1):15-18.

Allocca, C., Chen, Q., and Glicksman, L.R. (2003): Design Analysis of Single- Sided Natural Ventilation. Energy and Buildings, 35(8), 785-795.

Awbi HB. (2003), Ventilation of buildings, 2nd ed. New York, Taylor \& Francis,.

Ayinla, A.K. (2011) Effects of Natural Ventilation on Residents' Comfort in the Houses of the Traditional Core of Ogbomoso, Nigeria. An unpublished work for the Degree of Master of philosophy at the ObafemiAwolowo University (OAU), Ile - Ife, Nigeria.

Azwar, D.H. and Ghani, I. (2009). “The Importance of Green Space: Towards a Quality Living Environment in Urban Areas" Archnet-IJAR, International Journal of Architectural Research, Volume 3- Issue 1-March: 245-262. 
Billings, J.S. (1889). The principles of ventilation and heating and their practical

application

(2nd ed.). New York: The Sanitary Engineer.

Bojić M, Patou-Parvedy A, Boyer H (2013): Optimization of Thermal Comfort in Building Through Envelope Design. Building Services Engineering Research and Technology $\quad 23, \quad$ no. 2 119-125. Buildings, Tata McGraw-Hill Pub. Co., New York.

Braines, C. (2000). “A Forest of Other Issues” Landscape Design, no. 294, pp. 46-47.

Busch J.F., (1992): A Tale of Two Populations: Thermal Comfort in Air-Conditioned and Naturally Ventilated Offices in Thailand, Energy and Buildings 18 (3-4) 235-249.

Campbell, K. (2001). Rethinking Open Space, Open Space Provision and Management: A way

For-ward, Report Presented by Scottish Executive Central Research Unit, Edinburgh, Scotland, UK.

Carmona, M., Heath, T., Oc, T., and Tiesdell, S. (2003). Public Places Urban Spaces-The Dimensions of Urban Design, Oxford: Architectural Press p.159.

CDC. (2003), Guidelines for environmental infection control in health-care facilities. Morbidity and Mortality Weekly Report, 52 (RR-10).

Chand Ishwar (1976): Design aids for natural Ventilation in buildings. Lecture Program in Functional Aspects of Building Design, pp 24-26, CBRI, Rookie, India.

Chenvidyakarn, T. (2005). The impact of pre-cooling on multiple steady states in stack ventilation. Journal of Architectural/Planning Research and Studies, 3, 3-20.

Clarke D (2001): A Breath of Fresh Air. Hospital Development. 32(11), 13-17.

Clinch, J.P. \& Healy J.D. (2003): Valuing Improvements in Comfort From Domestic ～EnergyEfficiency Retrofits Using a Trade-Off Simulation Model. Energy $\quad$ Economics 25 (5): 565-583

Countrystudies (2012) An Online Publication Accessed in July, 2012 at: http://countrystudies.us/nigeria/33.htm

El-Agouz, S. A. (2008). The effect of internal heat source and opening locations on environmental natural ventilation. Energy and Buildings 40(4): 409-418.

Etheridge D, Sandberg M. (1996) Building ventilation - theory and measurement. $\quad$ Chichester, UK, John Wiley \& Sons.

Evola, G. and V. Popov (2006). Computational analysis of wind driven natural ventilation in buildings. Energy and Buildings 38(5): 491-501. 
Fadamiro, J.A. (2000). "Outdoor Spaces and their Landscape Qualities: A Comparative Analysis of Three Neighbourhoods in Lagos, Nigeria." Journal of Urban and $\quad$ Environmental Research, 2(1): $55-67$.

Fadamiro, J.A. and Atolagbe, A.M.O. (2006). "Urban Environmental Sustainability: A Challenge to Effective Landscaping in Nigeria” Dimensi Teknik Arsitektur Vol. $\quad$ 34,No.1， July $\quad$ 2006:44-51. Available at http://www.petra.as.id/-pusht/ ournals/dir.php? department ID=ARS.

Fang X., Bianchi M. V., Christensen C. (2012): Monetization of Thermal Comfort in Residential Buildings. ACEEE Summer Study on Energy Efficiency in Buildings.

Fanger, O., (1970), Thermal Comfort Analysis and Applications in Environmental Engineering. New York, McGraw Hill.

Finnegan J.J., Pickering C.A.C., and Burge P.S., (1994): The Sick Building Syndrome: Prevalence Studies, British Medical Journal 289 1573-1575.

Givoni, B. (1994). Passive and low energy cooling of buildings. New York: John Wiley \& Sons.

Groat, L. and D. Wang, (2002), Architectural Research Methods. New York: John Wiley \& Sons, Inc. Haruna, I. U., Musa, I., Tikau, M. I. and Yerima, M. (2014): Improvement of Thermal Comfort in Residential Buildings. International Journal of Scientific \& Technology Research Volume 3, Issue 3, March 2014

Hassan, M. A., N. M. Guirguis, et al. (2007). Investigation of effects of window combinations on ventilation characteristics for thermal comfort in buildings. Desalination 209 (1-3): 251-260.

Heier M (2013):

Heiselberg, P., K. Svidt, et al. (2001). Characteristics of air\$ow from open windows. Building and Environment 36: 859-869.

Heiselberg P, Bjørn E. (2002),Impact of open windows on room air-flow and thermal comfort. International Journal of Ventilation, 2002, 1(2):91-100.

Jagboro, G.O. (2000). Sustainable Development and Cost Behaviour of Landscape Elements in Urban Residential Buildings in Lagos Metro-polis in Effective Housing in the 21st Century Nigeria, O.B. Akinbamijo et al (eds.) pp. 96-100 Akure: The Environment Forum, Federal Uni-versity of Technology.

Jones, N. (2001). “Green Leaves”, Landscape Design, no. 299 pp. 30.

Krishan, A. (2001): Climate Responsive Architecture: A Design Handbook For Energy Efficient 
Kristian, F. and Tronchin, L. (2011): Thermal Comfort and Energy Performance of Buidling In Residential Building: A Commented Case Study In Ravenna, Italy. Proceedings of Building Simulation 2011: 12th Conference of International Building Performance Simulation Association, Sydney, 14-16 November.

Levermore G.J., (2002): The Exponential Limit to the Cooling Of Buildings by Natural Ventilation.

Liu, Y. (2003): Climate Analysis and Architectural Design Strategies for Bioclimatc.Design;

Dissertation for the degree of Doctor of Engineering in Xi' an University of Architecture and Technology.

Marsh, A. (2001): WEATOOL. The weather tool: Climate visualization and Design analysis. Perth, Australia.

Nationsencyclopedia.com (2012). An online Encyclopedia of the Nations Accessed in July at:http://www.nationsencyclopedia.com/Africa/Nigeria.

Ogunsote O.O. (1988): Introduction to Building Climatology. Ahmadu Bello University Press, Zaria, Nigeria.

Olufowobi, M.B. \& Adenuga, (2006) O.A Towards The Specification Of Windows Sizes $\quad$ For Natural Ventilation In Classrooms In A Warn Climate, Nigeria. Department of Building, University of Lagos, Akoka - Yaba, Lagos, Nigeria Corresponding author: oaadenuga@yahoo.com Ososana, C.O. (2002): Transformations in the Traditional Yoruba Dwelling: A casestudy of Ile-Ife, Journal of Environmental Technology, Federal University of Technology.

Oyelami, O.A. (2005). The Myth, The Mould and The Microbe, Inaugural Lectures Series 182

Obafemi Awolowo University, Ile-Ife O.A.U. Press Limited.

Rajasekar E. and Ramachandraiah A. (2010): Adaptive Comfort and Thermal Expectations _ A Subjective Evaluation in Hot Humid Climate. Proceedings of Conference: Adapting to Change: New Thinking on Comfort Cumberland Lodge, Windsor, UK, 9-11 April 2010. London: Network for Comfort and Energy Use in Buildings, http://nceub.org.uk.

Rangsiraksa, P. (2006): Thermal Comfort in Bangkok Residential Buildings, Thailand. The 23rd Conference on Passive and Low Energy Architecture, Geneva, Switzerland, 6-8 September 2006.

Sakka A., Wagner A. and Santamouris M. (2010): Thermal Comfort and Occupant Satisfaction in Residential Buildings. Proceedings of Conference: Adapting to Change: New Thinking on Comfort Cumberland Lodge, Windsor, UK, 9-11 April, $2010 . \quad$ London: Network for Comfort and Energy Use in Buildings, http://nceub.org.uk 
Sherman, M. (2004): American Society of Heating, Refrigerating and Air-conditioning Engineers (ASHRAE's), First Residential Ventilation Standard." Proceedings of Buildings IX Conference. Clearwater FL. LBNL-54331

Spengler, J.D. and Chen, Q. (2000): Indoor Air Quality Factors in Designing a Healthy Building, Annual Review of Energy and the Environment, 25, 567-600. Thermal Responses, Roomvent 2 351357. 4. J.J.

Tablada A, De Troyer F, Blocken B, Carmeliet J, Verschure H. (2009): On Natural Ventilation and Thermal Comfort in Compact Urban Environments - The Old Havana Case. Building and Environment 44(9): 1943-1958

Taleghani, M., Tenpierik, M. and Dobbelsteen, A. (2012): The Effect of Different Transitional Spaces on Thermal Comfort and Energy Consumption of Residential Buildings. Proceedings of 7th Windsor Conference: The changing context of comfort in an unpredictable world Cumberland Lodge, Windsor, UK, 12-15 April 2012. London:

Network for Comfort and Energy Use in Buildings, http://nceub.org.uk

Tantasavasdi, C., Srebric, J., \& Chen, Q. (2001). Natural ventilation design for houses in Thailand.

Energy and Buildings, 33, 815-824.

Tipple, G. (2001). "The Impact of Regulations on the Livelihoods of People Living in Poverty"available at http://practicalaction.org/docs/shelter/ G\%/20Tipple\%20Case\%20Studydoc, Accessed on 11/02/2010

Traveltips (2012) An online publication accessed in July, 2012 at: Smart Housing Queensland. Sustainable Design resource - Department of Housing, University Press.

University of California Ernest Orlando Lawrence Berkeley National Laboratory. Double-Skin Facades and Natural Ventilation. ～http://gaia.lbl.gov/hpbf/techno_c3.htm (accessed April 30, 2011).

USGBC, Cascadia Chapter. "Fact Sheet: Natural Ventilation" http://media.whatcounts.com/onenw_cgbc/August_2005/NATURALVENTILATIＯN.pdf (accessed July 30, 2010).

Willmert, T. (2001): The Return of Natural Ventilation. Architectural Record. 189(7), $\quad$ 137-148.

WHO. (2009):Natural Ventilation for Infection Control in Health-care Settings. Geneva Switzerland. pg 10. 
WorldAtlas.com (2012) An online publication accessed in July

World Bank (2013): Turn Down the Heat, Why a $4^{0} \mathrm{C}$ Warmer Must Be Avoided. A Report for the

World Bank by the Potsdam Institute for Climate Impact Research and Climate Analytics.

Zhao R., Xia Y., (1998): Effective Non-Isothermal and Intermittent Air Movement on Human. 